\title{
Inovasi Metode dan Media dalam Pembelajaran Seni di Sekolah
}

Arnita

Guru SMP Negeri 3 Kecamatan Payakumbuh, Kab. Lima Puluh Kota

\begin{abstract}
Abstrak
Penelitian ini bertujuan untuk mengetahui metode dan media pembelajaran yang dapat digunakan guru dalam pembelajaran seni budaya. Penelitian ini berisi tentang paparan studi kepustakaan. Selain itu, studi kepustakaan tersebut memuat konsep-konsep mengenai hakikat seni, karya seni, pembelajaran seni, fungsi dan kedudukan pembelajaran seni budaya, serta inovasi dan media pembelajaran seni budaya di sekolah. Berdasarkan konsep tersebut, dapat dipahami bahwa guru dapat memilih beberapa alternatif metode dan media yang tepat dalam pembelajaran seni budaya di sekolah, seperti: ceramah, diskusi, demonstrasi, latihan, pemecahan masalah, teman sejawat, karya wisata, dan lainnya serta beberapa media inovatif, seperti: media berbasis cetakan, media gambar, media audio, visual, media audiovisual, dan media berbasis manusia.
\end{abstract}

Kata kunci: pembelajaran seni, inovasi, metode, media

Copyright (C) 2017 IICET (Indonesia) - All Rights Reserved

Indonesian Institute for Counseling, Education and Theraphy (IICET)

\section{PENDAHULUAN}

Seorang Guru yang akan mendidik para siswanya dalam bidang pendidikan seni membutuhkan dasardasar pengetahuan dan keterampilan yang sesuai dengan tuntutan bidang tersebut Aritonang, K. T. (2008). Selanjutnya, Effendi, L. A. (2012) mengungkapkan guru memiliki pengaruh yang paling penting terhadap kemajuan siswa dalam proses pembelajaran.. Penguasaan dasar-dasar pengetahuan dan keterampilan tersebut meliputi pengetahuan tentang metode pembelajarannya Sudrajat, A. (2008). Metode pembelajaran seni merupakan dasar pengetahuan yang mesti dikuasai seorang guru ketika akan mempersiapkan diri dalam perancangan (desain) pembelajaran seni.

Metode secara harfiah berarti "cara", dalam pemakaian yang umum, metode diartikan sebagai suatu cara atau prosedur yang dipakai untuk mencapai tujuan tertentu Dasar, p. G. S. (2008). Sependapat dengan Rahman, R., \& Maarif, S. (2014) menjelaskan metode secara harfiah berarti cara, dan dalam pemakaian yang umum, metode diartikan sebagai cara melakukan suatu atau cara melakukan pekerjaan. Kata "pembelajaran" berarti segala upaya yang dilakukan oleh pendidik agar terjadi proses belajar pada diri siswa. Handhika, J. (2010) menjelaskan pembelajaran adalah setiap kegiatan yang dirancang untuk membantu seseorang mempelajari suatu kemampuan dan atau nilai yang baru. Selanjutnya, Pendidikan, B. S. N. (20070 mengemukakan pembelajaran merupakan proses interaksi peserta didik dengan guru dan sumber belajar pada suatu lingkungan belajar.

Adapun tujuan dari pemebelajaran adalah membuat tahu dan paham dan bukanlah hafalan Kontekstual, M. P. P. (2011). Sedangkan kegiatan pembelajaran merupakan suatu proses komunikasi Nurseto, T. (2012). Jadi, metode pembelajaran adalah cara-cara menyajikan materi pelajaran yang dilakukan oleh pendidik agar terjadi proses belajar pada diri siswa untuk mencapai tujuan. 
Salah satu keterampilan guru yang memegang peranan penting dalam proses pembelajaran adalah keterampilan memilih metode. Menurut Lepiyanto, A. (2011) guru harus mampu mendorong siswa aktif dalam pembelajran melalui penggunaan metode pembelajran yang variatif. Pemilihan metode berkaitan langsung dengan usaha-usaha guru dalam menampilkan pebelajaran yang sesuai dengan situasi dan kondisi sehingga pencapaian tujuan pembelajaran diperoleh secara optimal. Oleh karena itu, salah satu hal yang sangat mendasar untuk dipahami guru adalah bagaimana memahami kedudukan metode sebagai salah satu komponen bagi keberhasilan kegiatan pembelajaran yang sama pentingnya dengan komponen-komponen lain dalam keseluruhan komponen pendidikan. Nashar, N. (2015) menegaskan bahwa pemilihan metode pembelajaran sangat penting agar tujuan pembelajaran tercapai.

Menurut Astuti, W. W., Sukardi, F. S. F., \& Partono, P. (2012) penggunaan metode pembelajaran dalam proses belajar mengajar harus efektif dan selektif sesuai dengan pokok bahasan yang diajarkan. Pemilihan metode pembelajaran merupakan salah satu tugas guru sebagai fasilitator yang bertugas menyediakan lingkungan belajar bagi siswa. Ketidaksesuain metode yang dipilih oleh guru dalam pembelajaran akan berdampak pada prestasi siswa di sekolah.

Suharto, S. (2007) menjelaskan Pendidikan Seni Budaya merupakan salah satu mata pelajaran pada pendidikan sekolah yang bertujuan untuk mengembangkan pengetahuan serta melatih kreativitas peserta didik dalam bidang seni, budaya dan teknologi. Pada konsepnya, mata pelajaran ini tidak hanya melatih kemampuan kreativitas peserta didik saja, namun siswa saat ini juga dituntut untuk menuangkan ide dan gagasan, selanjutnya ide tersebut diterapkan dalam kehidupan sehari-hari. Oleh karena itu diperlukan metodemetode pembelajaran yang tepat oleh guru sehingga peserta didik dapat memahami materi pembelajaran seni budaya ini dengan baik.

\section{HASIL DAN PEMBAHASAN \\ Batasan Seni dan Karya Seni}

Seni merupakan suatu kegiatan yang secara sadar dilakukan manusia dengan mengunakan media tertentu untuk menyampaikan pemikiran dan perasaan kepada orang lain dalam bentuk visual, suara maupun gerakan. Seni diartikan sebagai sesuatu kegiatan manusia untuk menciptakan suatu benda bernilai keindahan, biasanya dilawankan dengan istilah craft. Hal yang membedakan art dengan craft ialah apabila seni bersifat perlambangan dan menciptakan realita baru, sedangkan kerajinan merupakan pekerjaan rutin yang ditujukan untuk kegunaan praktis (Flemming dalam The Liang Gie, 1976:62). Pendapat lain menyatakan bahwa seni adalah aktivitas batin dengan pengalaman estetis yang dinyatakan dalam bentuk agung yang mempunyai daya membangkitkan rasa takjub dan haru (Bastomi, 1982:11). Senada dengan hal tersebut, Ki Hajar Dewantara menjelaskan bahwa seni adalah segala perbuatan-perbuatan yang timbul dari perasaan yang bersifat indah sehingga menggerakkan jiwa dan perasaan manusia.

Menurut Flemming (dalam The Liang Gie, 1976:60), seni berarti bentuk kemampuan atau skill yang berasal dari bahasa latin art. Sejalan dengan itu, Sudarmaji (1979:5) menyebutkan bahwa seni dalam bahasa asing disebut art. Kata seni berasal dari bahasa Yunani mempunyai pengertian yang sangat luas. Namun, dapat dikatakan adanya hubungan antara seni dengan kemampuan, kecakapan, keterampilan, serta memuat nilai estetis yang menyangkut masalah kesenangan batin.

Darmawan (1988:40) menyatakan bahwa seni adalah usaha oleh manusia untuk menciptakan bentukbentuk yang menyenangkan, seni adalah emosi yang menjelma menjadi suatu ciptaan yang nyata, seni merupakan getaran jiwa dan keselarasan dan perasaan serta pikiran yang terwujud menjadi sesuatu yang indah. Hal ini menjelaskan bahwa seni berkaitan dengan ciptaan manusia yang memuaskan penciptanya dan memenuhi kebutuhan jiwa akan nilai keindahan. Adapun, nilai adalah segala sesuatu yang dianggap berharga yang melekat pada sesuatu termasuk pada karya seni. Nilai mengandung makna sifat atau kualitas dari segala 
sesuatu yang dipandang berharga atau bermanfaat dan oleh karena itu orang selalu mencarinya (Rondhi, 2002:11).

Berbicara mengenai seni tidak lepas dari karya seni. Karya seni merupakan produk atau hasil dari seni itu sendiri. Karya seni merupakan bentuk indrawi yang diciptakan manusia dengan meragakan perasaan terhadap suatu nilai (Sahman, 1993:29). Rondhi (2002:19) menjelaskan bahwa karya seni merupakan karya ciptaan manusia untuk diapresiasikan kepada penonton. Penonton merupakan orang-orang yang diharapkan mau menerima dan menghargai karya seni ciptaan seniman. Karya seni merupakan benda ciptaan manusia yang memuat banyak nilai seperti nilai keindahan, religi, mistis, historis, pendidikan, sosial dan nilai ekonomi.

\section{Menilik Kedudukan dan Fungsi Pendidikan Seni}

Pendidikan adalah suatu proses untuk mendewasakan manusia, karena pendidikan berkenaan dengan proses mempersiapkan pribadi yang utuh sehingga fokus pada masa depan bangsa. Pendidikan menyadarkan manusia tentang benar-salah dan baik-buruk. Dalam hal ini Nasution (dalam Bastian 2006:184) mengemukakan peningkatan kualitas pendidikan bangsa adalah salah satu solusi untuk mengatasi krisis multidimensional yang sedang melanda bangsa Indonesia.

Selanjutnya, pendidikan seni merupakan upaya sadar untuk menyiapkan siswa melalui kegiatan pembelajaran agar siswa memiliki pengalaman dalam berapresiasi dan berkreasi seni. Tujuan pendidikan seni di sekolah umum adalah bukan mewariskan keterampilan, melainkan memberikan pengalaman pada siswa dalam rangka untuk membantu pengembangan potensi yang dimilikinya terutama potensi perasaan (kecerdasan emosional) agar seimbang dengan kecerdasan intelektual (Jazuli, 2008:20). Menurut Ismiyanto (2010:34) tujuan pendidikan seni antara lain: mengembangkan kreativitas dan sensitivitas peserta didik, meningkatkan kapasitas dan kualitas pengetahuan kesenian peserta didik dan meningkatkan keterampilan peserta didik.Tujuan pendidikan seni adalah untuk menumbuhkembangkan sikap toleransi, demokrasi, beradab, serta mampu hidup rukun dalam masyarakat majemuk, mengembangkan kemampuan imajinatif intelektual, ekspresi melalui seni, mengembangkan kepekaan rasa, keterampilan, serta mampu menerapkan teknologi dalam berkreasi dan memamerkan atau mempergelarkan karya seni (Syafie i, 2006:30).

Pendidikan seni merupakan bagian integral dari pendidikan, artinya bahwa mata pelajaran seni merupakan salah satu bagian penting yang tidak dapat dipisahkan dari sistem pendidikan nasional. Terkait dengan itu, Sobandi (2008:46) berpendapat bahwa pendidikan seni merupakan alat untuk mencapai tujuan pendidikan. Sebagai akibatnya, pelaksanaan pendidikan seni harus menekankan pada segi proses, tidak pada produk. Proses pembelajaran seni mengupayakan terciptanya situasi dan kondisi yang kondusif bagi kegiatan belajar yang menyangkut ekspresi artistik dan menciptakan lingkungan yang dapat membantu perkembangan anak untuk menemukan sesuatu melalui eksplorasi dan eksperimentasi dalam belajar. Oleh karena itu, ditegaskan bahwa situasi dan kondisi serta suasana lingkungan menjadi hal yang sangat dominan dalam proses pembelajaran seni (Ismiyanto, 2010:22). Pendidikan seni pada dasarnya berfungsi sebagai pemenuhan kebutuhan berekspresi, berapresiasi, berkreasi, dan berekreasi anak. Selain itu sebagai media pemenuhan kebutuhan anak, pada hakikatnya pendidikan, termasuk pendidikan seni juga dimaksudkan sebagai upaya pelestarian sistem nilai oleh masyarakat pendukungnya.

Menurut Lowenfeld dan Brittain (dalam Ismiyanto 2010:2), pembelajaran kelas difokuskan pada hal-hal yang memungkinkan siswa terdorong dalam prosesnya. Oleh karena itu, dalam pembelajaran seni rupa harus diperhatikan tahap perkembangan anak, yang terpenting bukan hasil karya tetapi bagaimana proses anak dalam menghasilkan karya. Dalam proses pembelajaran seni rupa adalah mengupayakan terciptanya situasi dan kondisi yang kondusif bagi kegiatan belajar anak didik dan menciptakan lingkungan yang dapat membantu perkembangan anak untuk "menemukan" sesuatu melalui eksplorasi dan eksperimen dalam belajar. 
Fungsi pembelajaran seni rupa adalah untuk mendorong dan meningkatkan potensi pribadi siswa secara komprehensif meliputi kemampuan ekspresivitas, sensitivitas, dan kreativitas, serta berfungsi untuk mengkonservasi dan mengembangkan gagasan-gagasan nilai, pikiran tentang keindahan yang terdapat dalam masyarakat dan bangsa dari suatu generasi ke generasi berikutnya. Senada dengan hal tersebut, Goldberg menyatakan bahwa terdapat tiga cara mengintegrasikan seni dalam pembelajaran, yaitu learning about the arts (belajar tentang seni), learning with the arts (belajar dengan seni), dan learning through the arts (belajar melalui seni). Belajar dengan seni terjadi jika seni diperkenalkan kepada siswa sebagai cara untuk mempelajari materi pelajaran tertentu. Sebagai contoh, guru memperkenalkan lukisan Piet Mondrian dalam mengajarkan garis sejajar. Dalam hal ini, siswa belajar dengan bantuan bentuk seni yang memberikan informasi tentang materi pelajaran.

Materi pokok seni rupa meliputi aspek apresiasi seni, berkarya seni, kritik seni, dan penyajian seni. Apresiasi seni rupa berarti mengenal, memahami, dan memberikan penghargaan atau tanggapan estetis (respons estetis) terhadap karya seni rupa. Materi apresiasi seni pada dasarnya adalah pengenalan tentang konsep atau makna, bentuk, dan fungsi seni rupa. Apresiasi seni rupa dapat mencakup materi yang lebih luas, yaitu pengenalan seni rupa dalam konteks berbagai kebudayaan (Departemen Pendidikan Nasional, 2004). Materi pelajaran apresiasi seni meliputi pengenalan terhadap budaya lokal, budaya daerah lain, dan budaya mancanegara, baik yang bercorak primitif, tradisional, klasik, moderen, maupun kontemporer. Selain pengenalan bentuk-bentuk seni rupa, materi apresiasi juga meliputi pengenalan tentang latar belakang sosial, budaya, dan sejarah di mana karya seni rupa dihasilkan serta makna-makna dan nilai-nilai pada seni rupa tersebut.

Pendidikan seni memiliki peranan dalam pembentukan pribadi siswa yang harmonis dalam logika, estetik dan etika dengan memperhatikan kebutuhan perkembangan anak dalam mencapai kecerdasan spiritual, moral, kreativitas dengan cara mempelajari prinsip, proses dan teknis berkarya sesuai dengan nilai budaya dan keindahan serta sesuai dengan konteks sosial budaya masyarakat sebagai sarana untuk menumbuhkan sikap saling memahami, menghargai dan menghormati. Belajar dengan seni ialah mengekespresikan diri dengan cara memahami bahasa rupa, bunyi, gerak, dan peran dalam perpaduannya. Belajar melalui seni ialah memahami konsep, menampilkan sikap apresiasi dan kreatifitas melalui seni dan budaya. Belajar tentang seni ialah mengembangkan kesadaran tentang konsep, apresiasi dan kreasi melalui upaya eksplorasi, proses dan teknik berkarya dalam konteks budaya masyarakat yang beragam. Pendidikan seni melibatkan semua bentuk kegiatan berupa aktivitas fisik dan cita rasa keindahan (estetik).

Aktivitas fisik dan cita rasa keindahan itu tertuang dalam kegiatan berekpresi, berekplorasi, berapresiasi berkreasi melalui bahasa rupa, bunyi, gerak dan peran yang masing-masing mencakup materi sesuai dengan bidang seni dan aktivitas dalam gagasan-gagasan seni, keterampilan berkarya serta apresiasi dengan memperhatikan konteks sosial budaya masyarakat. Pembelajaran seni di sekolah umum pada dasarnya diarahkan untuk menumbuhkan kepekaan rasa estetik dan artistik sehingga terbentuk sikap kritis, apresiatif dan kreatif pada diri siswa secara menyeluruh. Sikap ini hanya mungkin tumbuh jika dilakukan serangkaian proses kegiatan pengalaman, penilaian, serta penumbuhan rasa memiliki melalui keterlibatan siswa dalam segala aktivitas seni di dalam kelas atau di luar kelas.

\section{Inovasi Metode Pembelajaran Seni Budaya di Sekolah}

Pendidikan seni sebagai mata pelajaran pada pendidikan sekolah didasarkan pada pemikiran bahwa pendidikan seni memiliki sifat multilingual, multidimensional, dan multikultural. Multilingual berarti melalui pendidikan seni dikembangkan kemampuan mengekspresikan diri dengan berbagai bahasa rupa, bunyi, gerak, dan paduannya. Multidimensional berarti dengan seni dapat dikembangkan kompetensi dasar siswa yang mencakup persepsi, pengetahuan, pemahaman, analisis, evaluasi, apresiasi, dan produktivitas dalam menyeimbangkan fungsi otak kanan dan kiri, dengan memadukan unsur logika, etika dan estetika. 
Multikultural berarti pendidikan seni bertujuan menumbuhkembangkan kesadaran dan kemampuan berapresiasi terhadap keragaman budaya lokal dan global sebagai pembentukan sikap menghargai, toleran, demokratis, beradab, dan hidup rukun dalam masyarakat dan budaya yang majemuk (Depdiknas 2001:7).

Tujuan pendidikan seni juga dapat dilihat sebagai upaya untuk mengembangkan sikap agar siswa mampu berkreasi dan peka terhadap seni atau memberikan kemampuan dalam berkarya dan berapresiasi seni. Kedua jenis kemampuan ini menjadi penting artinya karena dinamika kehidupan sosial manusia dan nilai-nilai estetis mempunyai sumbangan terhadap kebahagiaan manusia di samping mencerdaskannya. Pendidikan seni, dapat dijadikan sebagai salah satu sarana dalam membentuk jiwa dan kepribadian siswa. Hal ini sejalan dengan apa yang dinyatakan oleh Plato (dalam Rohidi 2000:79) bahwa pendidikan seni dapat dijadikan dasar untuk membentuk kepribadian. Dalam hubungan ini seni merupakan bidang ilmu yang perlu dipelajari dan diapresiasi oleh peserta didik karena mengandung nili-nilai dan bermanfaat dalam kehidupan manusia. Oleh karenanya diperlukan rancangan yang berkaitan dengan proses pelaksanaan pembelajaran seni, baik kurikulum, metode, sarana maupun alat penunjangnya, dan juga tidak meninggalkan lingkungan sosial budaya setempat.

Dalam penerapan metode pembelajaran seni budaya tidak terlepas juga dari interaksi antara guru dengan siswa selama proses belajar mengajar berlangsung. Dengan adanya interaksi inilah, proses penyampaian materi ajar akan lebih mudah dan komunikatif. Ada beberapa metode pembelajaran yang dapat digunakan guru pada pembelajaran seni budaya, diantaranya:

a. Metode Ceramah

Metode pembelajaran ceramah adalah penerangan secara lisan atas bahan pembelajaran kepada sekelompok pendengar untuk mencapai tujuan pembelajaran tertentu dalam jumlah yang relatif besar. Seperti ditunjukkan oleh Mc Leish (1976), melalui ceramah, dapat dicapai beberapa tujuan. Dengan metode ceramah, guru dapat mendorong timbulnya inspirasi bagi pendengarnya. Gage dan Berliner (1981:457), menyatakan metode ceramah cocok untuk digunakan dalam pembelajaran dengan ciri-ciri tertentu. Ceramah cocok untuk penyampaian bahan belajar yang berupa informasi dan jika bahan belajar tersebut sukar didapatkan.

b. Metode Diskusi

Metode pembelajaran diskusi adalah proses pelibatan dua orang peserta atau lebih untuk berinteraksi saling bertukar pendapat, dan atau saling mempertahankan pendapat dalam pemecahan masalah sehingga didapatkan kesepakatan di antara mereka. Pembelajaran yang menggunakan metode diskusi merupakan pembelajaran yang bersifat interaktif (Gagne dan Briggs, 1979:251). Menurut Mc. Keachie-Kulik, dari hasil penelitiannya, dibanding metode ceramah, metode diskusi dapat meningkatkan anak dalam pemahaman konsep, dan keterampilan memecahkan masalah. Dalam transformasi pengetahuan, penggunaan metode diskusi hasilnya lambat dibanding penggunaan ceramah sehingga metode ceramah lebih efektif untuk meningkatkan kuantitas pengetahuan anak dari pada metode diskusi.

c. Metode Demonstrasi

Metode pembelajaran demontrasi merupakan metode pembelajaran yang sangat efektif untuk menolong siswa mencari jawaban atas pertanyaan-pertanyaan seperti: Bagaimana cara mengaturnya? Bagaimana proses bekerjanya? Bagaimana proses mengerjakannya. Demonstrasi sebagai metode pembelajaran adalah bilamana seorang guru atau seorang demonstrator (orang luar yang sengaja diminta) atau seorang siswa memperlihatkan kepada seluruh kelas sesuatau proses. Misalnya, demonstrasi cara memainkan alat musik talempong pacik. Kelebihan metode demonstrasi adalah perhatian siswa dapat lebih dipusatkan, proses belajar siswa lebih terarah pada materi yang sedang dipelajari, dan pengalaman dan kesan sebagai hasil pembelajaran lebih melekat dalam diri siswa. Kelemahan metode demonstrasi adalah siswa kadang kala sukar melihat dengan jelas benda yang diperagakan, tidak semua benda dapat 
didemonstrasikan, dan sukar dimengerti jika didemonstrasikan oleh pengajar yang kurang menguasai apa yang didemonstrasikan.

d. Metode Ceramah Plus

Metode pembelajaran ceramah plus adalah metode pengajaran yang menggunakan lebih dari satu metode, yakni metode ceramah yang dikombinasikan dengan metode lainnya. Ada tiga macam metode ceramah plus, diantaranya, yaitu: (1) metode ceramah plus tanya jawab dan tugas, (2) metode ceramah plus diskusi dan tugas, dan (3) metode ceramah plus demonstrasi dan latihan (CPDL).

e. Metode Resitasi

Metode pembelajaran resitasi merupakan salah satu metode pengajaran dengan mengharuskan siswa membuat resume dengan kalimat sendiri. Kelebihan metode resitasi merupakan pengetahuan yang diperoleh peserta didik dari hasil belajar sendiri akan dapat diingat lebih lama, dan peserta didik memiliki peluang untuk meningkatkan keberanian, inisiatif, bertanggung jawab dan mandiri. Kelemahan metode resitasi adalah kadang kala peserta didik melakukan penipuan yakni peserta didik hanya meniru hasil pekerjaan orang lain tanpa mau bersusah payah mengerjakan sendiri. Selain itu, kelemahan lain terkadang tugas dikerjakan oleh orang lain tanpa pengawasan dan sukar memberikan tugas yang memenuhi perbedaan individual.

f. Metode Eksperimental

Metode pembelajaran eksperimental adalah suatu cara pengelolaan pembelajaran di mana siswa melakukan aktivitas percobaan dengan mengalami dan membuktikan sendiri suatu yang dipelajarinya. Dalam metode ini, siswa diberi kesempatan untuk mengalami sendiri atau melakukan sendiri dengan mengikuti suatu proses, mengamati suatu obyek, menganalisis, serta membuktikan dan menarik kesimpulan sendiri tentang obyek yang dipelajarinya.

g. Metode Study Tour (Karya wisata)

Metode study tour (karya wisata) adalah metode mengajar dengan mengajak peserta didik mengunjungi suatu objek guna memperluas pengetahuan tentang seni dan budaya dan selanjutnya peserta didik membuat laporan dan mendiskusikan serta membukukan hasil kunjungan tersebut dengan didampingi oleh pendidik.

h. Metode Latihan Keterampilan

Metode latihan keterampilan (drill method) adalah suatu metode mengajar dengan memberikan pelatihan keterampilan secara berulang kepada peserta didik, dan mengajaknya langsung ketempat latihan keterampilan untuk melihat proses tujuan, fungsi, kegunaan dan manfaat sesuatu (misalnya, membuat batik tradisional). Metode latihan keterampilan ini bertujuan membentuk kebiasaan atau pola yang otomatis pada peserta didik.

i. Metode Pengajaran Beregu

Metode pembelajaran beregu adalah suatu metode mengajar dimana pendidiknya lebih dari satu orang yang masing-masing mempunyai tugas. Biasanya, salah seorang pendidik ditunjuk sebagai kordinator. Cara pengujiannya,setiap pendidik membuat soal, kemudian digabung. Jika ujian lisan, maka setiap siswa yang diuji harus langsung berhadapan dengan team pendidik tersebut.

j. $\quad$ Metode Peer Theaching

Metode peer theaching sama juga dengan mengajar sesama teman, yaitu suatu metode mengajar yang dibantu oleh temannya sendiri.

k. Metode Pemecahan Masalah (Problem Solving Method) 
Metode problem solving (metode pemecahan masalah) bukan hanya sekadar metode mengajar, tetapi juga merupakan suatu metode berpikir, sebab dalam problem solving dapat menggunakan metode-metode lainnya yang dimulai dengan mencari data sampai pada menarik kesimpulan. Metode problem solving merupakan metode yang merangsang berpikir dan menggunakan wawasan tanpa melihat kualitas pendapat yang disampaikan oleh siswa. Seorang guru harus dapat merangsang siswanya untuk mencoba mengeluarkan pendapatnya.

\section{Inovasi Media Pembelajaran Seni Budaya di Sekolah}

Media pembelajaran yang digunakan guru pada pembelajaran seni budaya, yaitu: (1) media berbasis cetakan (buku paket atau LKS), (2) media berbasis visual (gambar), (3) media audio visual, contohnya: TV, (4) media audio berupa VCD player dan kaset CD, (5) media berbasis manusia, guru berperan sebagai instruktur, dan (6) media audio, guru dalam mengajar menggunakan media, seperti: tape recorder, VCD player, dan kaset atau menggunakan gamelan sebagai musik iringan tari.

\section{SIMPULAN DAN SARAN}

Metode pembelajaran pada pembelajaran seni budaya merupakan suatu rancangan yang sangat diperlukan dalam proses pembelajaran. Pendidikan seni dan budaya bertujuan sebagai upaya untuk mengembangkan sikap agar siswa mampu berkreasi dan peka terhadap seni dan budaya atau memberikan kemampuan dalam berkarya dan berapresiasi seni. Kedua jenis kemampuan ini menjadi penting karena dinamika kehidupan sosial budaya manusia dan nilai-nilai estetis mempunyai sumbangan terhadap kebahagiaan manusia di samping mencerdaskannya. Dengan kata lain, pendidikan seni merupakan salah satu sarana dalam membentuk jiwa dan kepribadian siswa. Ini berarti pembelajaran seni budaya mengandung nilinilai yang bermanfaat dalam kehidupan manusia. Oleh karena itu, guru sebagai tenaga pengajar hendaknya mampu menggunakan metode yang tepat dalam proses pembelajaran, disamping itu penggunaan media pebelajaran juga dibutuhkan unutuk menunjang proses pembelajaran menjadi lebih baik, sehingga materi mengenai seni budaya dapat dipahami oleh siswa. Tentunya diharapkan pemahaman siswa terhadap seni dan budaya ini dapat diaplikasikan dalam kehidupan sosial sehingga bermanfaat bagi kemajuan bangsa.

\section{DAFTAR RUJUKAN}

Anas, Banarul. (2000). Refleksi Seni Rupa. Jakarta: Balai Pustaka.

Aritonang, K. T. (2008). Minat dan motivasi dalam meningkatkan hasil belajar siswa. Jurnal Pendidikan Penabur, 7(10), 11-21.

Astuti, W. W., Sukardi, F. S. F., \& Partono, P. (2012). Pengaruh Motivasi Belajar dan Metode Pembelajaran terhadap Hasil Belajar IPS Terpadu Kelas VIII SMP PGRI 16 Brangsong Kabupaten Kendal. Economic Education Analysis Journal, 1(2).

Bastian, I. (2006). Akuntansi Pendidikan. Jakarta: Erlangga.

Bastomi, S .(1982). Seni Rupa Indonesia. Semarang: IKIP Semarang.

Darmawan, A. (1988). Kajian Seni Budaya Nusantara. Jakarta: Hasta Karya.

Darsono, S, K. (2004). Seni Rupa Modern. Bandung: Rekayasa Sains.

Dasar, p. G. S. (2008). Metode pembelajaran.

Departemen Pendidikan Nasional. (2004). Pedoman Diagnostik Potensi Peserta Didik.

Depdiknas. (2006). Kamus Besar Bahasa Indonesia. Jakarta: Balai Pustaka.

Effendi, L. A. (2012). Pembelajaran matematika dengan metode penemuan terbimbing untuk meningkatkan kemampuan representasi dan pemecahan masalah matematis siswa SMP. Jurnal Penelitian Pendidikan, 13(2).

Handhika, J. (2010). Pembelajaran Fisika Melalui Inkuiri Terbimbing dengan Metode Eksperimen dan Demonstrasi Ditinjau dari Aktivitas dan Perhatian Mahasiswa1. Jurnal Penelitian Pembelajaran Fisika, 1(1/april).

Ismiyanto. (2009). "Pembelajaran Seni Rupa." Handout. Semarang: Jurusan Seni Rupa FBS Universitas Negeri Semarang. 
Ismiyanto. (2010). “Metode Penelitian.” Buku Ajar. Semarang: Jurusan Seni Rupa Fakultas Bahasa dan Seni UNNES.

Jazuli. (2008). Paradigma Kontekstual Pendidikan Seni. Semarang: Unesa University Press.

Kontekstual, M. P. P. (2011). Penelitian tindakan kelas.

Lepiyanto, A. (2011). Membangun karakter siswa dalam pembelajaran biologi. BIOEDUKASI (Jurnal Pendidikan Biologi), 2(1).

Nashar, N. (2015). Pengaruh Metode Pembelajaran dan Kemampuan Berpikir Kritis Terhadap Hasil Belajar Sejarah Siswa. Jurnal Candrasangkala Pendidikan Sejarah, 1(1), 18-23.

Nurseto, T. (2012). Membuat media pembelajaran yang menarik. Jurnal Ekonomi \& Pendidikan, 8(1).

Pendidikan, B. S. N. (2007). Standar Proses untuk Satuan Pendidikan Dasar dan Menengah. Badan Standar Nasional Pendidikan.

Prawira, Nanda Ganang. (2000). Pendekatan dan Metode Pembelajaran Seni Rupa. Malang.

Rahman, R., \& Maarif, S. (2014). Pengaruh Penggunaan Metode Discovery terhadap Kemampuan Analogi Matematis Siswa SMK Al-Ikhsan Pamarican Kabupaten Ciamis Jawa Barat. Infinity Journal, 3(1), 3358.

Rohidi, T.R. (2000). Kesenian dalam Pendekatan Kebudayaan. Bandung : STSI Bandung.

Rondhi, Moh. (2002). “Tinjauan Seni Rupa 1.” Buku Ajar. Semarang: Jurusan Seni Rupa Fakultas Bahasa dan Seni Universitas Negeri Semarang.

Sahman, H. (1993). Mengenal Dunia Seni Rupa: Tentang Seni, Karya Seni, Aktifitas Kreatif, Apresiasi, Kritik, dan Estetika. Semarang: IKIP Semarang Press.

Salam, S. (2002). Paradigma dan Masalah Pendidikan Seni. Universitas Negeri Semarang. Semarang.

Simamora, Roymond H. (2009). Buku Ajar Pendidikan Dalam Keperawatan. Jakarta : EGC.

Sobandi, B. (2008). Karakteristik Lukisan/Gambar Anak. Solo: Maulana Offset.

Sudarmaji. (1979). Dasar-dasar Kritik Seni Rupa. Yogyakarya: ASTRIM.

Sudrajat, A. (2008). Pengertian pendekatan, strategi, metode, teknik, taktik, dan model pembelajaran. Online)(http://smacepiring. wordpress. com).

Suharto, S. (2007). Pengembangan Materi dan Kegiatan Pembelajarannya dalam Kurikulum Tingkat Satuan Pendidikan Bidang Seni Musik. Harmonia: Journal Of Arts Research And Education, 8(3).

Sulikah. (2012). http://sulikah26.blogspot.co.id/2012/07/seni-sebagai-media-pendidikan_22.html. (Diakses: 6 November 2015).

Syafi'i. (2006). “Konsep dan Model Pembelajaran Seni Rupa.” Handout. Semarang: Jurusan Seni Rupa FBS Universitas Negeri Semarang.

Syarifudin. (2012). Pendidikan dan Pemberdayaan Masyarakat. Medan: Perdana Publishing.

The Liang Gie.(1976). Garis Besar Estetika (Filsafat Keindahan). Yogyakarta: Pusat Ilmu Berguna. 